\title{
Petrophysical Investigation of the Khurmala Formation in Taq Taq Oil Field, Zagros Folded Belt
}

\author{
Fraidoon Rashid ${ }^{1}$, Devan O. Hussein ${ }^{2}$ and Hawar A. Zangana ${ }^{3}$ \\ ${ }^{1}$ Department of Engineering, Kurdistan institution for Strategic Study and Scientific Research, \\ Sulaimani, Kurdistan Region - F.R. Iraq \\ ${ }^{2}$ Department of Geology, College of Science, University of Sulaimani, \\ Sulaimani, Kurdistan Region - F.R. Iraq
}

${ }^{3}$ Department of Petroleum and Energy Engineering, College of Engineering, Sulaimani Polytechnic University, Sulaimani, Kurdistan Region - F.R. Iraq

\begin{abstract}
The Tertiary rocks of Khurmala Formation in the Taq Taq oil field have been studied using wireline log analysis, drilling cutting descriptions with integration of mud logging report, and test results for understanding reservoir potentiality and fluid distribution. The formation comprised dolostone and dolomitic limestone with an intercalation of clay layers between the recognized beds. The formation has variable thickness throughout the field, $99.8 \mathrm{~m}$ from the northeastern limb and $109 \mathrm{~m}$ in the southeastern plunge. The calculated shale volume in the studied interval shows a high rate of the clay contents which in some points the gamma ray has $100 \%$ of shale. The corrected log-derived bulk porosity subdivided the Khurmala Formation into 5 porosity units from the top to the bottom including (Kh-1, Kh-2, Kh-3, Kh-4, and Kh-5). The first (Kh-1), third (Kh-3), and fifth $(\mathrm{Kh}-5)$ porosity units have the average porosity $\geq 0.10(10 \%)$ that can be considered as good reservoir unit in terms of porosity, whereas the shale contents reduced the reservoir quality of these units. However, well hydrocarbon entrapment through interconnected fractures and fault in the other Tertiary reservoir was recorded in Taq Taq field, but the weak connectivity of the pores in the Khurmala Formation caused this rock interval remains as water bearing zone.
\end{abstract}

Index Terms-Hydrocarbon, Khurmala, Porosity, Reservoir.

\section{INTRODUCTION}

Carbonate rocks are represented the dominant productive reservoir type in the Middle East (Hollis, 2011; Hollis et al., 2017; Jafarian et al., 2017; Adam et al., 2018) and this area holds nearly $15 \%$ of the world hydrocarbon reserves (Normi and Standen, 1997). The Iraqi Zagros basin is characterized by extension of different petroleum systems and heterogonous distribution of reservoir types including Triassic (Ryder Scott, 2011), Jurassic (Sherwani and Zangana, 2017), Cretaceous

ARO-The Scientific Journal of Koya University Vol. VIII, No.1 (2020), Article ID: ARO.10556, 12 pages DOI:10.14500/aro.10556

Received 30 July 2019; Accepted 12 January 2020

Regular research paper: Published 20 February 2020

Corresponding author's e-mail: fraidoon.rashid@kissr.edu.krd

Copyright (C) 2020 Fraidoon Rashid, Devan O. Hussein,

Hawar A. Zangana. This is an open-access article distributed under the Creative Commons Attribution License.
(Al-Qayim and Rashid, 2012; Rashid, 2015; Rashid et al, 2015a and b; Rashid et al., 2017; Ghafur and Hasan, 2017; Rashid et al., 2020), and Tertiary reservoir rocks (Al-Qayim and Othman, 2012; Hussein, 2015; Hussein et al., 2017; and Hussein et al., 2018).

The Tertiary reservoir rocks have interrupted extensions and their availability was eliminated by local deposition of specific successions in a limited area. The tree dominant reservoir rocks in the Tertiary petroleum system in the Zagros folded zone are Kirkuk group, Euphrates, and Jeribe Formations (Jassim and Goff, 2006). However, in the Kirkuk oil field including Avanah and Khurmala domes, the Eocene Avanah Formation and Paleocene Sinjar Formation are considered as a productive reservoir rock (Aqrawi et al., 2010). Furthermore, the Eocene Pilaspi Formation identified as anisotropic reservoir rock units throughout the structures of Zagros basin in the Kurdistan region from Chamchamal block, Taq Taq and Tawke fields (Garland et al., 2010; Mackertich and Samarrai, 2015).

In contrast, the Paleocene Khurmala Formation has not recognized as a productive reservoir rock within the newly discovered fields in the Kurdistan region and also in the previously proved fields in the Kirkuk embayment. As a result, the rock evaluations of this formation were not analyzed and a very limited study about the reservoir characterization of this interval in the tertiary petroleum system has been considered, for understanding its reservoir potentiality. In this study, subsurface data sets from Taq Taq oil field were selected for evaluating the petrophysical properties and the reservoir quality of the Khurmala Formation to find out the logical reasons that influenced the rock ability for store hydrocarbon and production efficiency.

\section{Geologic Setting}

Kurdistan region and Northern Iraq can be subdivided into three major structural unit areas, each unit has distinct structural characteristics and stratigraphic successions. Thrust Zone is characterized by highly complex tectonics with steep folds and over thrusts. The Folded Zone contains a series of anticlinal folds, having NW-SE trends, generally double plunging, in successive rows of parallel elongated closures, varying in axial 
length and width. The Folded Zone enriched with a proved several oil and gas fields including Kirkuk, Khabaz, Bai Hassan, Jambur, Taq Taq, and Shaikan fields. The third zone is a narrow imbricated zone that appeared adjacent to the thrust belt front.

The Folded Zone can be subdivided into two areas (zones) based on geomorphologic criteria and geological distribution of the sedimentary beds; High and Low Folded zones, (Ameen, 1992; Aqrawi et al., 2010, Jassim and Goff, 2006, Zebari and Burberry, 2015). These areas separated by the Mountain Front Fault, defined as the southern and southwestern, exposing of white limestone Pilaspi Formation, Fig. 1a. The High Mountains Zone is an intensely folded area north and

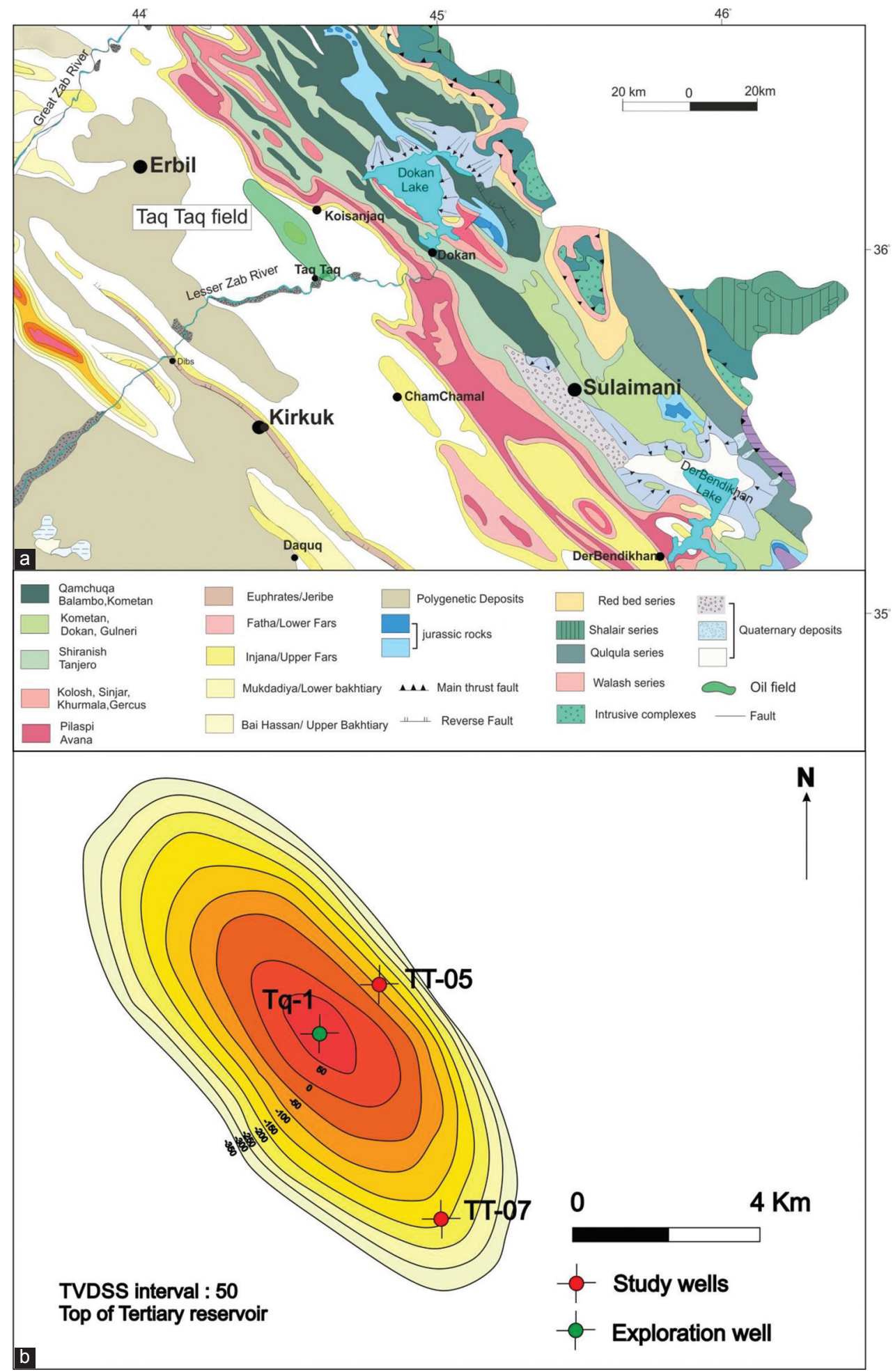

Fig. 1. (a). Geologic map of the Kurdistan region and north of Iraq shows the location of the Taq Taq oil field, modified from Sissakian et al., 2000. (b). Taq Taq field structure, contour on top of the Tertiary reservoir (NOC, 1987). The contours (contour interval = 50 m) measured from the ground surface. The selected well locates on the northeast and southwest of well Tq-1, crest of the Taq Taq anticline. 


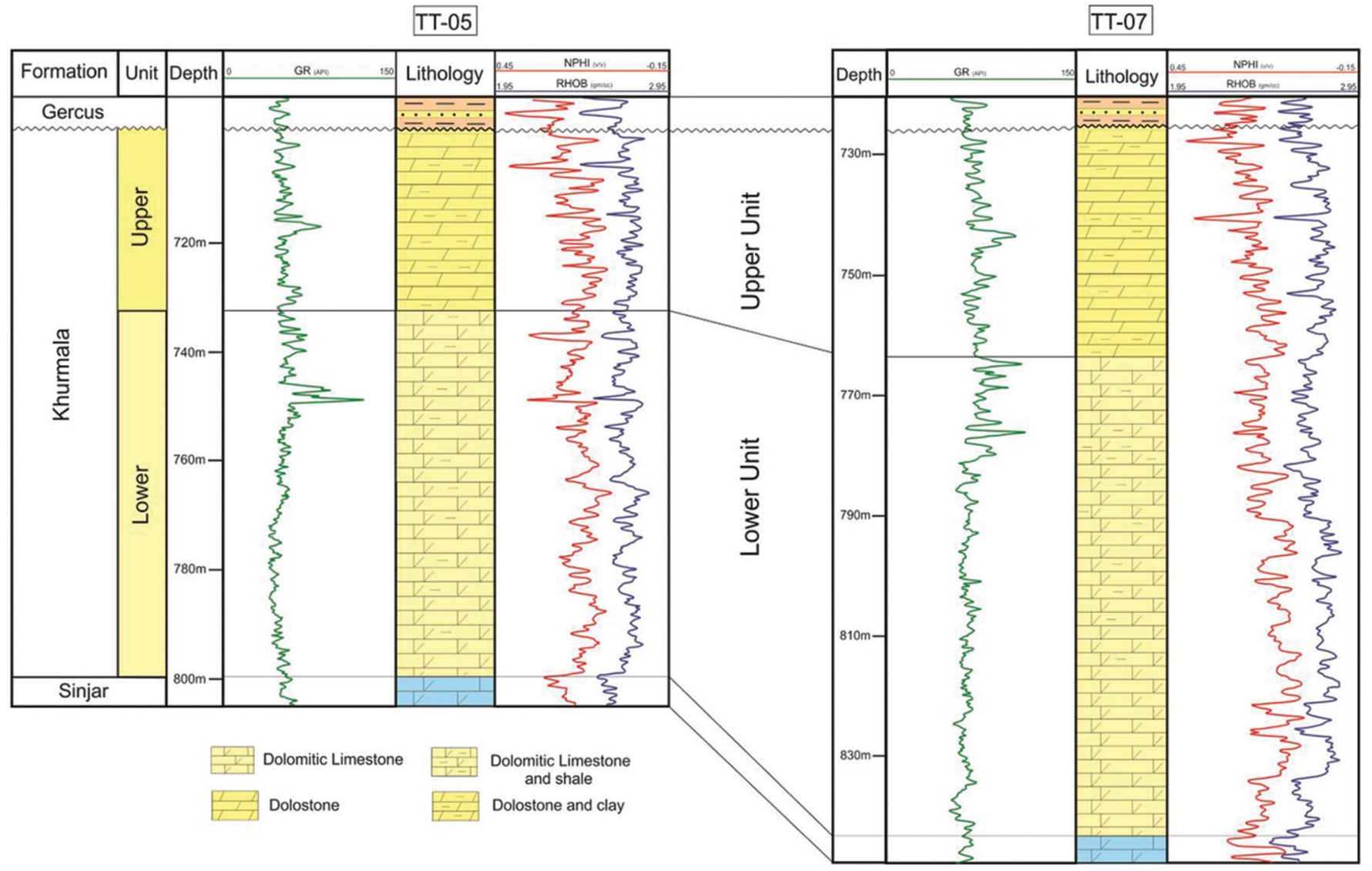

Fig. 2. Lithostratigraphic division of the Khurmala Formation in well TT-05 and TT-07 derived from wireline logs and lithologic description of cutting samples. The Khurmala Formation divided into two lithological units including upper unit (dolostone) and lower unit (dolomitic limestone). The calcareous clay and shale distributed within these two units.

northeast of the Mountain Front, in which different ages of rock units including Eocene, Palaeocene, and Cretaceous rocks were cropping out. The Low Folded Zone is the less intensely folded area located to the south and southwest of the Mountain Front, commonly Fars and Bakhtiari Formations can be seen at the exposure surfaces of this zone.

Taq Taq structure is a well-defined surface double-plunging anticline, oriented NW-SE parallel to the other structures in the Low Folded Zone of Zagros. The surface expression of the anticline has $27 \mathrm{~km}$ length of longitudinal axis and $11 \mathrm{~km}$ width, at an elevation of around $600 \mathrm{~m}$ above the sea level. The geological map of the area shows that the Pliocene-Pleistocene Upper Fars-Lower Bakhtiari Formations are cropped out at the surface on and surrounded area of the anticline. Toward the north, the older Eocene, Palaeocene, and Upper Cretaceous rocks equivalent to the Taq Taq reservoirs exposed in the mountains. The penetrated formations in the Taq Taq field starts from Miocene Lower Fars Formation at the Surface to the Jurassic Sargelu Formation in well Tq-1 and Upper Qamchuqa Formation in the most drilled wells, Fig. 1b. The dominant targets in this field were Cretaceous formation including Upper Qamchuqa Formation (Al-Qayim and Rashid, 2012), Kometan Formation (Rashid et al., 2015a), Shiranish Formation (Garland et al., 2010), and Tertiary Pilaspi Formation (Al-Qayim and Othman, 2010; Al-Qayim and Othman, 2012).

\section{Materials And Methodologies}

The data sets of this study were gathered from two drilled wells in the Taq Taq field including TT-05 and TT-07. The wells were penetrated all the targets and reached to the Upper Qamchuqa Formation successfully during the development program of the field. Well TT-05 is vertical developed well, located about $500 \mathrm{~m}$ of the northeast side of the first exploration well Tq-1 that was drilled on the crest of the structure. Well TT-07 is a deviated appraisal well which was drilled about $2500 \mathrm{~m}$ of the southeastern position of well Tq-1 on the southern plunge in the crestal part of the field.

The collected data for this research comprise a petrophysical wireline log covered the drilled Khurmala Formation intervals. The log data consist of porosity logs (sonic, density, and neutron), gamma ray logs, and resistivity logs. Besides the log data, drilling stem test, mud log, lithologs, and cutting samples have been used as a supporting evidence to enhance the quality of the study. A summary of the gathered data is shown in Table I.

The raw materials of the wireline logs have been used to identify the lithological distribution, mineralogical components, shale contents, porosity calculation, and fluid movability in the Khurmala Formation using Interactive Petrophysics. The petrophysical outcomes of the log data 
TABLE I

Summary of the Collected Data from the Taq Taq field

\begin{tabular}{|c|c|c|}
\hline$\overline{\text { Data }}$ & TT-05 & TT-07 \\
\hline Wireline log & $\begin{array}{l}\text { Gamma ray (GR), sonic (DT), } \\
\text { compensated density log } \\
\text { (CDL), compensated neutron } \\
\log (\mathrm{CNL})\end{array}$ & $\begin{array}{l}\text { Gamma ray (GR), sonic } \\
\text { (DT), compensated density } \\
\log (\mathrm{CDL}) \text {, compensated } \\
\text { neutron } \log (\mathrm{CNL})\end{array}$ \\
\hline Cutting sample & 50 & 50 \\
\hline Well test & Drilling stem test & Drilling stem test \\
\hline Mud log & Mud losses report & Mud losses report \\
\hline
\end{tabular}

TABLE II

Statistical Parameters of the Calculated Shale Volume from Gamma RAY LOGS

\begin{tabular}{llccccc}
\hline \hline Well & $\begin{array}{l}\text { Lithology } \\
\text { Unit }\end{array}$ & Minimum & Maximum & $\begin{array}{c}\text { Standard } \\
\text { deviation }\end{array}$ & Mean & Mode \\
\hline TT-05 & Upper & 0.011 & 0.262 & 0.039 & 0.055 & 0.038 \\
& Lower & 0.000 & 0.393 & 0.048 & 0.046 & 0.026 \\
& Overall & 0.000 & 0.393 & 0.045 & 0.049 & 0.038 \\
TT-07 & Upper & 0.04 & 0.58 & 0.09 & 0.13 & 0.10 \\
& Lower & 0.01 & 1.00 & 0.10 & 0.10 & 0.06 \\
& Overall & 0.01 & 1.00 & 0.10 & 0.11 & 0.06 \\
\hline \hline
\end{tabular}

were dominantly achieved from the common equations and charts that have been used in wireline log analysis.

\section{A. Lithology}

The lithological description of the drilled cutting samples was integrated with the wireline lithology identification resulted from log combination method (Ellis and Singer, 2007; Asquith and Krygowski, 2004; Wiley and Pachett, 1990; Dahlberg, 1989), density-neutron log cross plot (Rider and Kennedy, 2011; Krygowski, 2003; Schlumberger, 1997). The conventional porosity logs are dependable on porosity change, lithology variation, and fluid contents. This criterion can be used to identify lithology composition and fluid type content in different rocks. The overlapping and crossover between the neutron and density logs are the dominant combination method for lithology determination. Furthermore, the cross plot between the neutron and a density $\log$ provides an essential result for continuous lithological variations in logged interval. This method gives single lithology component or a mixture between two types of rocks as limestone, dolostone, or dolomitic limestone.

\section{B. Shale Volume}

The gamma ray log can be used to calculate the volume of shale (clay) in a given interval. The estimated volume is usually shown as a decimal fraction or percentage is called shale volume $\left(\mathrm{V}_{\mathrm{sh}}\right)$. In the carbonate rocks, the magnitude of the shale volume possibly affected by existence of organic matter because organic matter can concentrate uranium. The gamma ray index $\left(\mathrm{I}_{\mathrm{GR}}\right)$ is the first step of the shale volume calculation using Equation (1), from the shale baseline (gamma reading $=100 \mathrm{API}$ ), clean sand line (gamma reading $=0.0 \mathrm{API}$ ), and the gamma ray log reading from the selected interval (Bhuyan and Passey, 1994). The calculated gamma ray index $\left(\mathrm{I}_{\mathrm{GR}}\right)$ then converts to shale volume with using the most appropriate equation. In this study, we have used (Larionov, 1969) equation for calculating shale volume in Tertiary (young) rocks, Equation (2).

$$
\begin{aligned}
I_{G R} & =\frac{G R_{\log }-G R_{\min }}{G R_{\max }-G R_{\min }} \\
V_{s h} & =0.083\left(2^{3.7 I_{G R}}-1\right)
\end{aligned}
$$

$I_{G R}:$ Gamma ray index

$G R_{\text {log }}$ : Gamma ray reading from $\log$, API

$G R_{\min }$ : Minimum gamma ray reading (clean sand or carbonate), API

$G R_{\text {max }}$ : Maximum gamma ray reading (shale), API

$V_{s h}:$ Shale volume.

\section{Porosity}

Sonic, density, and neutron logs are frequently referred to as porosity logs and they are widely used for calculating porosity in formation evaluation and reservoir quality assessment. Porosity must be calculated from the sonic slowness using Wiley time average Equation (3), (Wiley and Pachett, 1990; Asquith and Krygowski, 2004) and the apparent density knowing values for these parameters for the matrix and the fluids occupying the pores with applying Equation (4). In addition, the hydrogen concentration immediately transferred to neutron porosity while reading the logged interval (Rider and Kennedy, 2011; Schlumberger, 2012). The total porosity was achieved from the average value of the density derived porosity and neutron porosity.

$$
f_{s}=\frac{\left(\Delta_{t b u l k}-\Delta_{t m a}\right)}{\left(\Delta_{t f l}-\Delta_{t m a}\right)}
$$

$\phi_{s}$ : Sonic porosity, fraction

$\Delta_{\text {tbulk }}$ : Sonic $\log$ reading, $\mu \mathrm{s} / \mathrm{ft}$

$\Delta_{t m a}:$ Transit time of matrix, $\mu \mathrm{s} / \mathrm{m}$

$\Delta_{t f f}:$ Transit time of the mud filtrate, $\mu \mathrm{s} / \mathrm{m}$.

$$
f_{r}=\frac{\left(r_{m a}-r_{b u l k}\right)}{\left(r_{m a}-r_{f l}\right)}
$$

$\phi_{\rho}$ : Density porosity, fraction

$\rho_{m a}:$ Matrix density, $\mathrm{g} / \mathrm{cm}^{3}$

$\rho_{\text {bulk }}$ : Log reading density, $\mathrm{g} / \mathrm{cm}^{3}$

$\rho_{f:}:$ Fluid density, $\mathrm{g} / \mathrm{cm}^{3}$.

Both the density and neutron tools use nuclear measurements, whereas the sonic tool measures the acoustic measure properties of the rock. Combination of three porosity logs in petrophysical measurement provides an accurate value of the calculated porosity from wireline logs. In this study, the estimated porosity was achieved from the porosity logs corrected for shale contents and environmental impaction. 


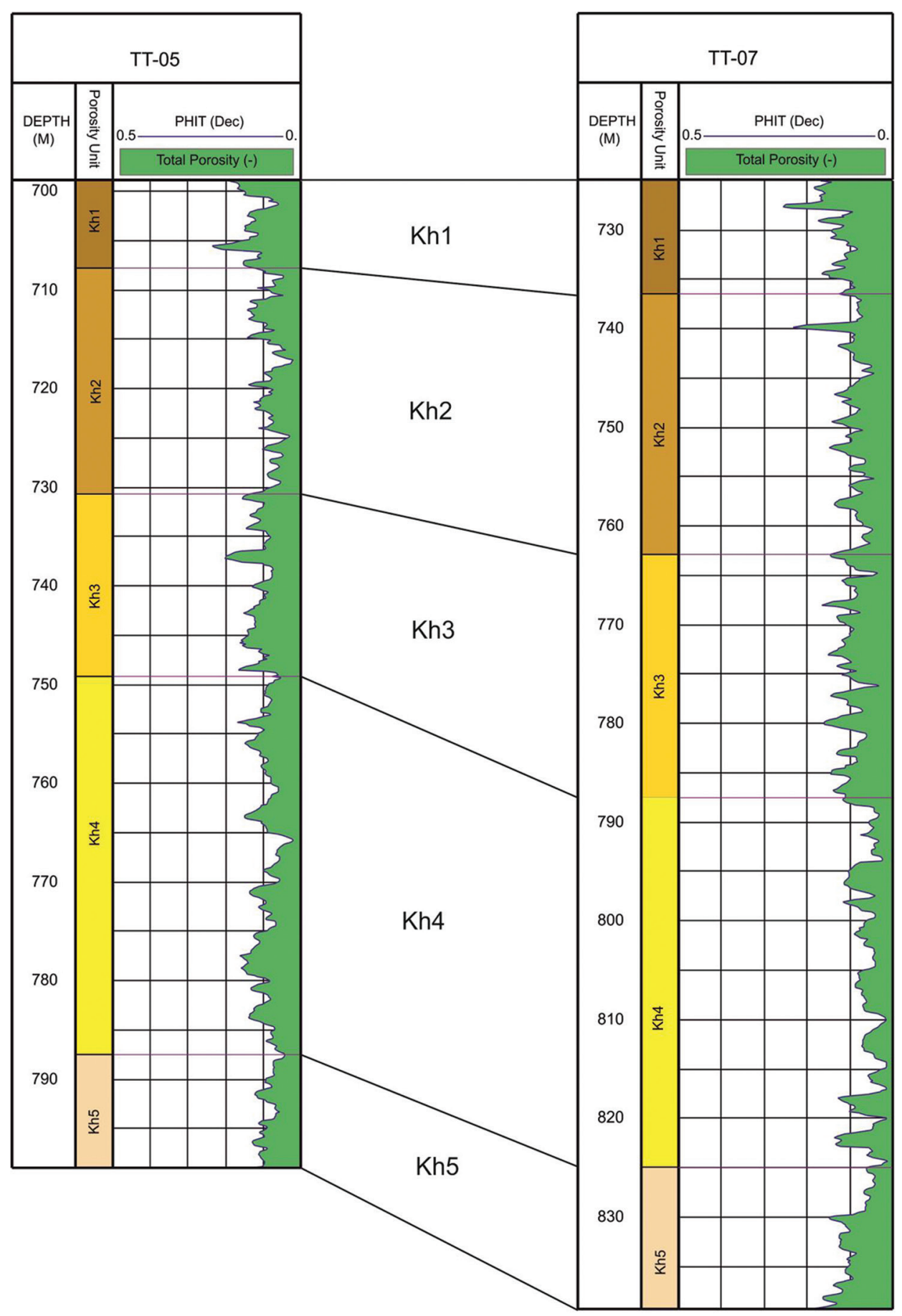

Fig. 3. Porosity distribution throughout the studied wells in the Taq Taq oil field, TT-05 and TT-07. The calculated total porosity was achieved from wireline logs and the studied interval subdivided into five porosity units from the top to the bottom of the formation.

\section{RESULTS}

\section{A. Lithology}

The Khurmala Formation lithologically consists of dolostone and limestone beds in the well K-114 of Kirkuk oil field (Van Bellen et al., 1959). This composition changed to limestone successions with intercalation of argillaceous, gypsum, and anhydrate beds in the well Ch-2 from the Chamchamal block and argillaceous limestone and marls in the outcrop sections of the Zagros folded belt (Jassim and Goff, 2006; Aqrawi et al., 2010). The thickness of the formation is adequately changeable throughout the Zagros folded belt in the subsurface and outcrops. The extension of gypsum and anhydrite within the carbonate beds is evidenced for restricted lagoon depositional environment of the Khurmala Formation.

The Khurmala Formation in the studied wells mostly comprises thick, fairly uniform, dolostone and dolomitic limestone with intercalation of clay beds and argillaceous limestone within the successions. The thickness of the formation is about $98.8 \mathrm{~m}$ in TT-05 and $113.8 \mathrm{~m}$ in TT07. These lithology components divided the Khurmala Formation in the Taq Taq 

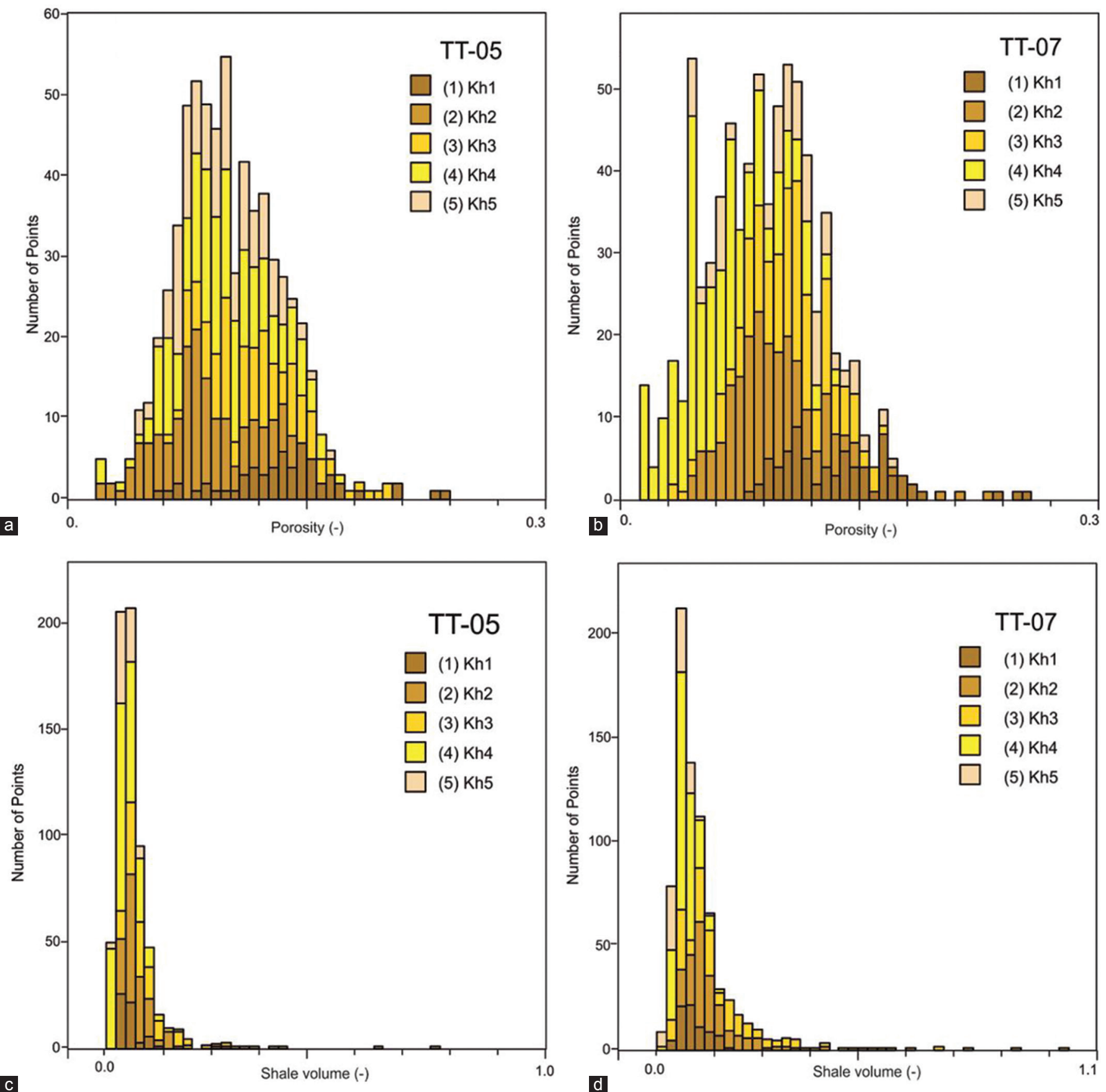

Fig. 4. Histograms of the total porosity and shale volume distribution throughout porosity units in the studied wells. (a) and (b) The total porosity distribution in the identified porosity units in well TT-05 and TT-07, respectively. (c) Shale volume distribution in well TT-05 and (d) shale volume distribution in TT-07.

field into two lithologic units; upper and lower lithologic units. The upper part is dominantly consisting of dolostone rocks with a calcareous clay (shale) contents. Thickness of this unit is about $31.3 \mathrm{~m}$ in TT-05, Fig. 2 and $37.6 \mathrm{~m}$ in TT-07 and overlaid by Gercus Formation. The dolostone rocks are characterized by light olive-gray to greenish-gray, firm to slightly hard, sub-blocky, locally crystalline texture. Visible pores cannot be investigated from the cutting samples.

Lower unit is comprised dolomitic limestone with intercalation of low amount shale layers in comparison to the upper part. Thickness of this unit is about $67.5 \mathrm{~m}$ in TT-05 and $76.2 \mathrm{~m}$ in TT-07 and overlies by Sinjar Formation. The dolomitic limestone is pale gray to dark gray, hard blocky to angular, predominantly fine microcrystalline, occasionally micritic, microsucrosic texture. Very rare visible pores can be seen using naked eye observation. Occasionally, vuggy pores have been observed in the lower part of the formation. Dark gray to olive-gray calcareous shale intercalated with the dolomite and dolomitic beds that are characterized by platy to subplaty and fissile shape. In addition, moderately gray to dark and opaque and extremely hard and angular chert 

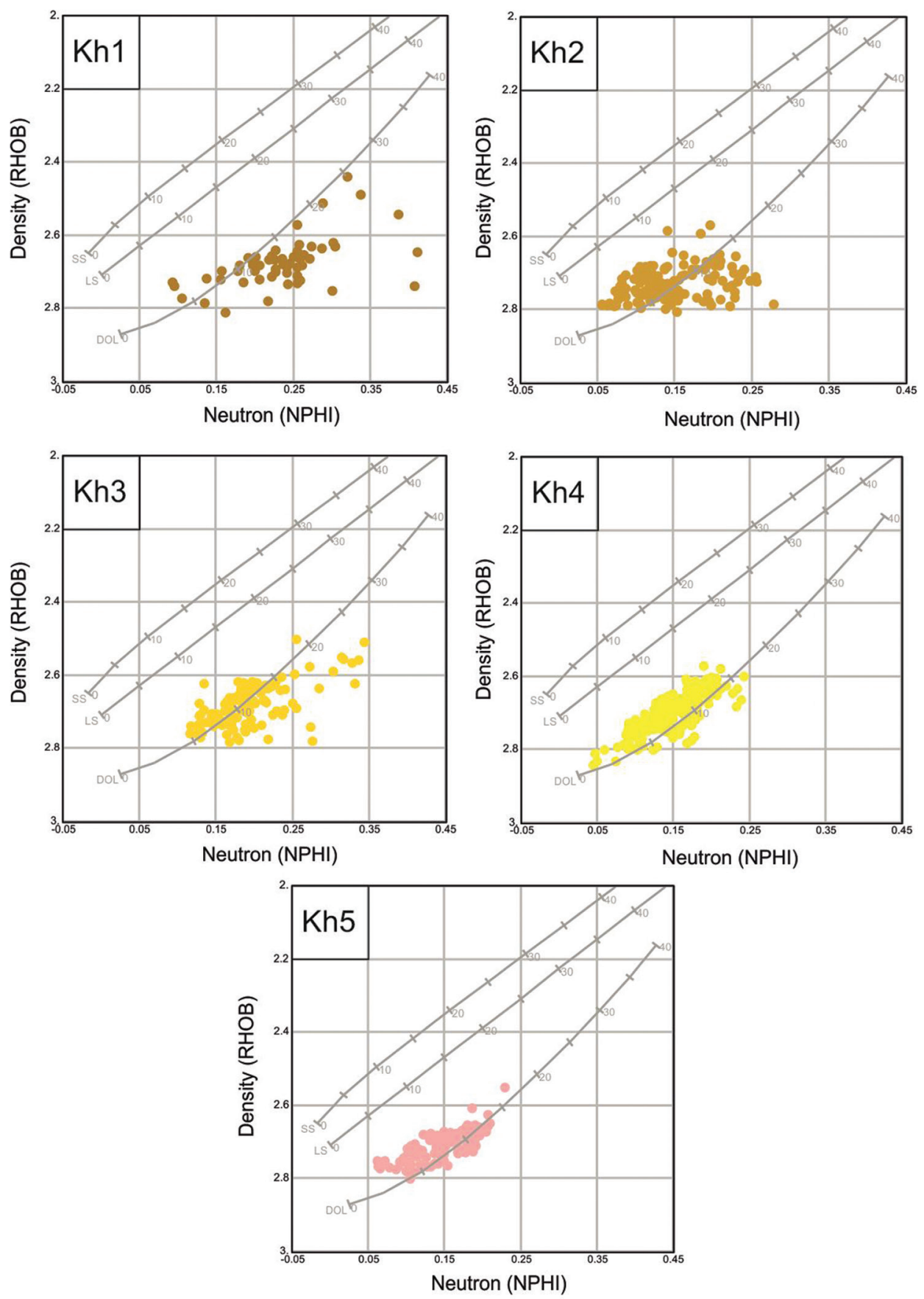

Fig. 5. Density-neutron cross plots of the Khurmala Formation in well TT-05 show different lithology components of the identified porosity units.

have been recorded in the lower part of the Khurmala Formation.

\section{B. Shale Volume}

The calculated volume of shale was obtained from the gamma ray log data using the Equations (1) and (2), respectively, for the studied intervals. The magnitude of the shale volume in the Khurmala Formations changed obviously from the top to the bottom and heterogeneous distribution of the shale percentage can be observed. Overall, the percentages of shale contents in the formation are quite high as reached
$26 \%$ in the upper part of the formation in TT-05 and 57\% in well TT-07. This magnitude was increased to $40 \%$ in TT05 and $100 \%$ in shale-bearing interval in TT- 07 . The static results of the estimated shale volume of the studied wells are presented in Table II.

\section{Porosity}

The porosity distributions were achieved from the average values of the density log-derived porosity and the neutron-derived porosity of the Khurmala Formation presented as a total porosity. Based on the deflection of 

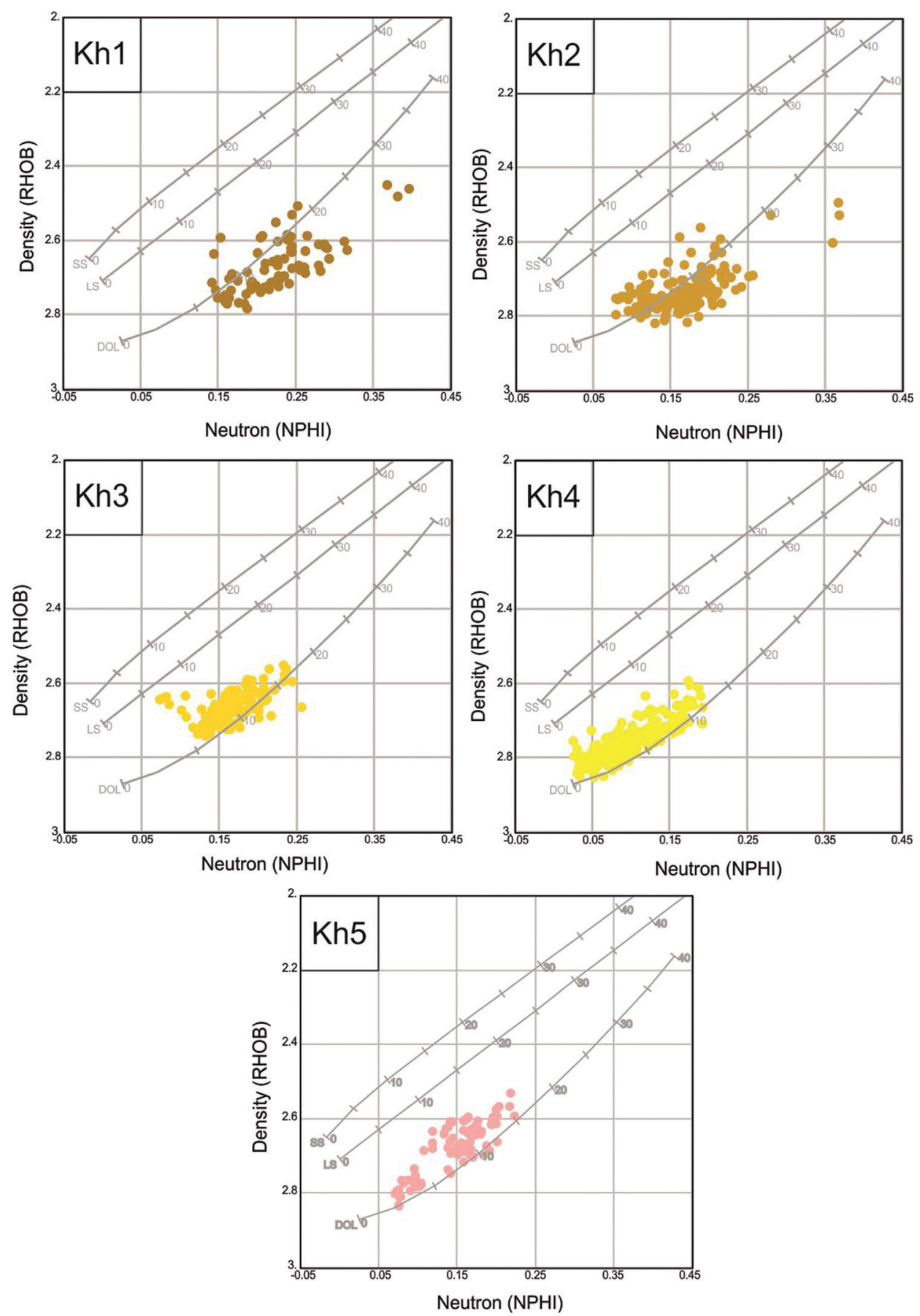

Fig. 6. Density-neutron cross plots of the Khurmala Formation in well TT-07 show different lithology components of the identified porosity units.

the total porosity curves, the total porosity distribution throughout the studied well can be subdivided into 5 units from the top to the bottom of the formation, respectively, Fig. 3.

\section{Kh-1 Porosity Unit}

The first unit is named Kh-1 covered the upper part of the Khurmala Formation in the Taq Taq oil field. The thickness of this unit is about $8.83 \mathrm{~m}$ in TT-05 and $11.5 \mathrm{~m}$ in TT-07, where Gercus Formation overlies this unit throughout the field, Fig. 2. The magnitude of the average calculated total porosity in this unit is about 0.14, Fig. $4 \mathrm{a}$ and $\mathrm{b}$, that is considered as the highest porosity value between the identified porosity units. The maximum clay volume in this unit is about 0.12 with an average of 0.04 throughout the unit, Fig. 4c and d. The lithology of this unit dominantly composed of dolostone (dolomite) as the plotted data from the density-neutron cross plot fall over the dolomite line with some movement toward the shale zone, Figs. 5 and 6. 

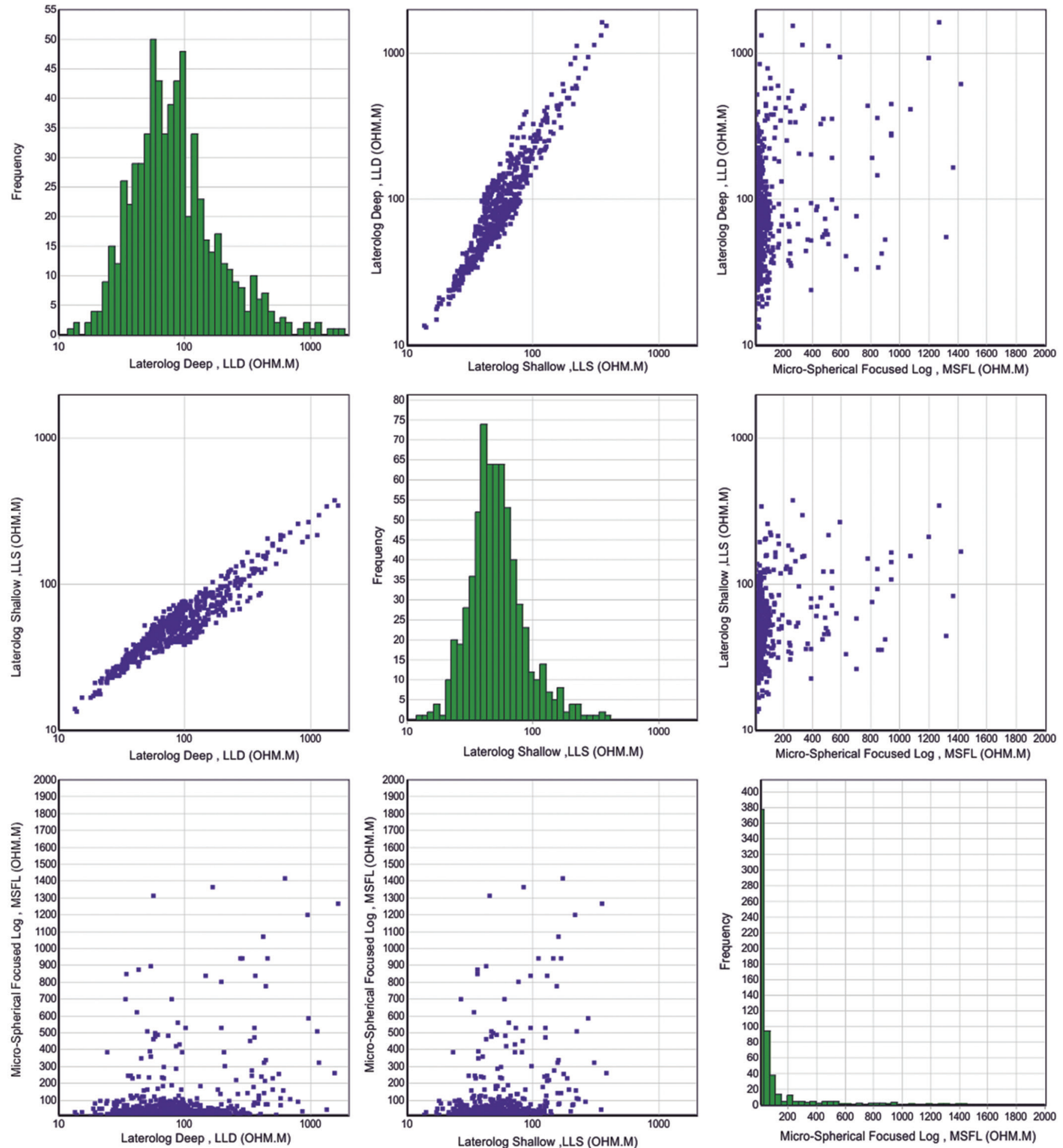

Fig. 7. Multicross plots of the resistivity logs including laterolog shallow (LLS), laterolog deep (LLD), and microspherically focused log (MSFL) of the Khurmala Formation in well TT-05. LLD and LLS readings are closed together, whereas the MSFL shows scattering readings for the same interval.

\section{Kh-2 Porosity Unit}

The second porosity unit (Kh-2) is located at the bottom of the first unit throughout the studied wells. The thickness of this unit is about $23 \mathrm{~m}$ in TT- 05 and $26.7 \mathrm{~m}$ in TT-7. The magnitude of the average calculated total porosity was achieved from the wireline $\log$ in this unit which is about 0.09 .
The maximum clay volume in this unit is 0.26 with an average of 0.06 throughout the unit in TT- 05 . The clay contents of this unit in TT-07 increased obviously and reached 0.57 as the maximum value and average is 0.14 . The lithology of this unit dominantly composed of dolostone (dolomite) and dolomitic limestone in TT-05 and dolomite in well TT-07. 


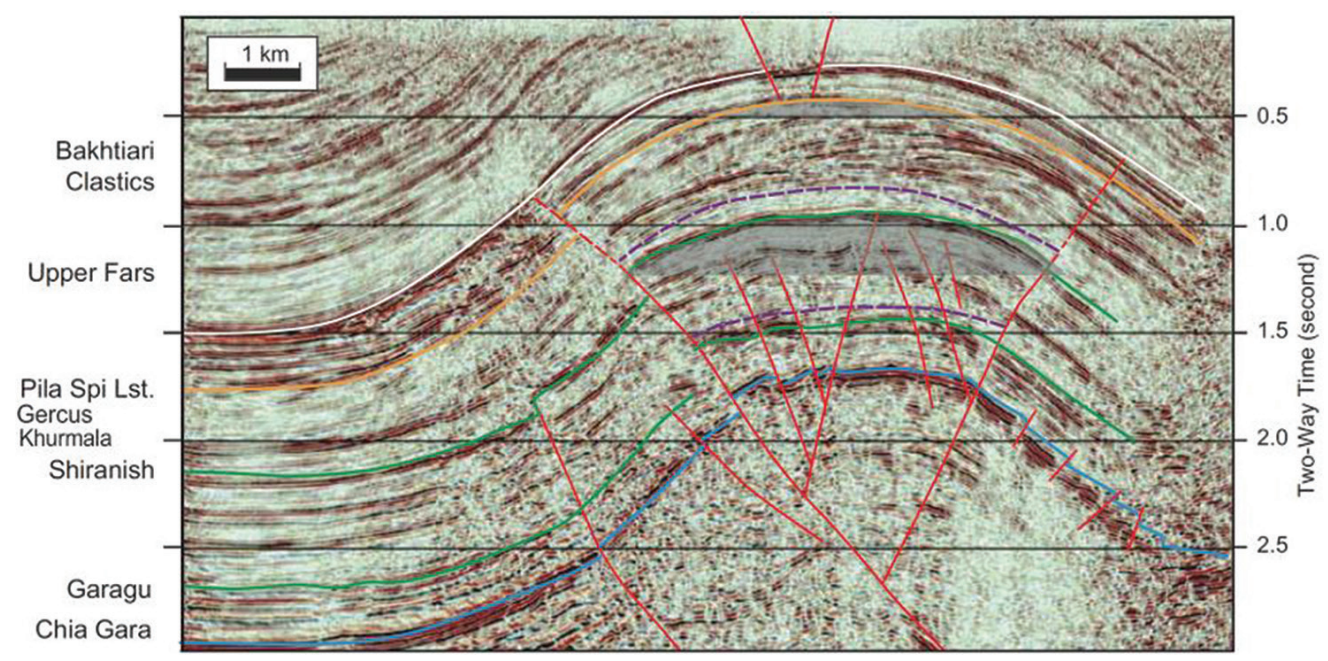

Fig. 8. Structural-seismic cross-section across the Taq Taq oil field with the stratigraphic succession and through going faults modified from Mackertich and Samarrai, 2015.

\section{Kh-3 Porosity Unit}

$\mathrm{Kh}-3$ is the third porosity unit that is placed below the second unit (Kh-2) throughout the studied intervals in the Taq Taq field. The thickness of this unit is about $18.10 \mathrm{~m}$ in TT-05 and $23.4 \mathrm{~m}$ in TT-7. The magnitude of the average calculated total porosity was achieved from the wireline $\log$ in this unit which is 0.11 . The shale volume within this porosity is much higher than the other units. The maximum clay volume in this unit is 0.39 with an average of 0.09 throughout the unit in TT-05. The clay contents of this unit in TT-07 increased obviously and reached 0.17 as the maximum value and average of 1.0. The lithology of this unit dominantly composed of dolostone rocks.

\section{Kh-4 Porosity Unit}

The fourth porosity unit (Kh4) in the Khurmala Formation has the thickest interval in the studied wells; $38.5 \mathrm{~m}$ thick in well TT-05 and TT-07. The average determined total porosity for this unit is 0.085 , and the maximum shale volume in this unit is 0.15 with an average of 0.050 . The clay content in this unit is much lower than the two previous units. The lithological composition of this unit as drawn from the density-neutron cross plot is dominantly composed of dolomitic limestone and the majority of the plotted data fall between the calcite and dolomite lines.

\section{Kh-5 Porosity Unit}

The last porosity unit (Kh-5) is located at the bottom of the Khurmala Formation and its thickness is $11.58 \mathrm{~m}$ in well TT-05 and $13.23 \mathrm{~m}$ in well TT-07. The average corrected total porosity in this unit is 0.10 , and the percentage of shale volume reached 0.085 and the average shale content is 0.040 . This unit can be considered as the cleanest interval in terms of the shale contents. The lithology of this unit consists of dolomitic limestone, it is a mixture of calcite and dolomite minerals based on the plotted data. This unit is overlaid by dolomitic limestone beds of the Sinjar Formation in the Taq Taq field.

\section{Discussion}

The Khurmala Formation lithologically comprised dolomitic limestone and dolomite rocks, and these lithologies have a potential to hold and transmit hydrocarbons in reservoir rocks. The calculated porosity in the studied wells is high enough to be considered as a productive reservoir rocks, especially the first (Kh-1), third (Kh-3), and fifth (Kh-5) porosity units as the average corrected total porosity is $>0.10(>10 \%)$ similar to the matrix porosity in Upper Qamchuqa and Pilaspi reservoir rocks (Al-Qayim and Othman, 2012; Al-Qayim and Rashid, 2012). However, after mud losing while drilling, a formation test flown sulfurous water at 3840 bpd in Tq-1 and saline water in TT-05 and TT-07 (NOC, 1987, Taq Taq Operation Company, 2006 and 2007). Furthermore, a very limited and minor oil were recorded only throughout the studied field.

High resistivity fluctuations were recorded by the microspherically focused resistivity log (microspherically focused $\log$ ) in a clean borehole section throughout the studied intervals, Fig. 7. This is interpreted as a fracture zone with high resistivity relevant to cemented fractures and low resistivity to open fractures. Nevertheless, matching between deep and shallow resistivity in the Khurmala Formation associated to a lack of oil is strong arguments supporting the saline water formation hypothesis. Thus, these interval reservoirs are considered as water bearing.

The problematic point for the reservoir evaluation in the Khurmala Formation is lack of hydrocarbon productivity with good reservoir porosity. In addition, the formation is overlaid by Gercus Formation that acted as cap rock for the underlined reservoir rocks. The fluid productivity in this interval can be linked with hydrocarbon migration and entrapment or pore connectivity and permeability distribution.

To explain the fluid migration and hydrocarbon charge into the pore spaces of the Khurmala Formation, we have selected the Pilaspi Formation for comparison in the same wells and field. The Pilaspi Formation is characterized by oil-bearing reservoir rocks in Taq Taq field (Al-Qayim and Othman, 


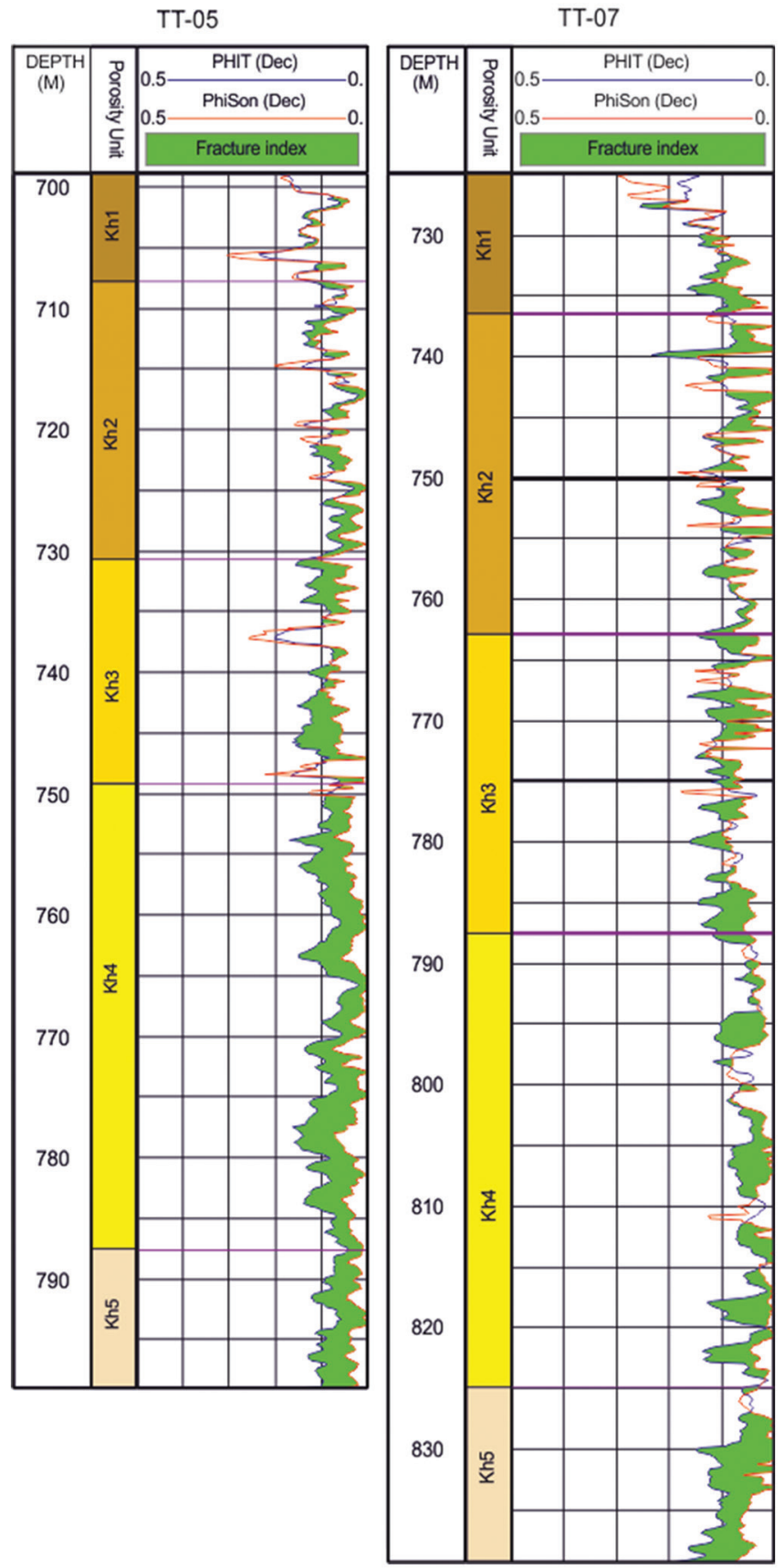

Fig. 9. Fracture index and secondary porosity distributions were obtained from the difference between total porosity (average porosity from the density and neutron log-derived porosity) and sonic log-derived porosity, showing as light green shadow zones.

2012). The hydrocarbon distribution in this reservoir is entrapped by fracture interconnected network, for example, through going fault that already crossed the Khurmala Formation, Fig. 8, that entrapped Pilaspi Formation and left the Khurmala Formation dry in terms of hydrocarbon saturation. The missing of the hydrocarbon in the pore spaces of the Khurmala Formation can be related with the volume of shale content. The formation can be considered as shale rock because of the volume of shale content $>10 \%(0.10)$ (Kamel and Mabrouk, 2003). Shale contents within dolomitic limestone and dolomite rocks destroyed the reservoir quality and blocked the pore connectivity and consequently reduced the magnitude of permeability. Besides the clay contents, the origins of the pores are dominantly secondary pore origin and this result can be seen clearly from the different contrast of the magnitude of log-derived porosity from sonic log and density-neutron logs, Fig. 9. The secondary pores commonly are characterized by weak interconnection between pores, isolated distribution and have very low permeability. These factors all together prohibited the migrated oil through fracture pathways to accumulate within the Khurmala Formation in the tertiary petroleum system.

\section{CONCLUSIONS}

The main concluded points from the reservoir characterization evaluation and petrophysical investigation from wireline logs, test results, mud logging, and cutting samples of the Khurmala Formation are listed as follows:

- The Khurmala Formation in the Taq Taq oil field lithologically consists of dolomite (upper unit) and dolomitic limestone (lower unit) rocks. Argillaceous clay and fissile shale are intercalated with these carbonate rock units hetrogenetically from the top to the bottom of the studied intervals

- The total corrected porosity achieved from the combination of density and neutron logs divided the formation into five respectful porosity units from the top to the bottom including (Kh-1, Kh-2, Kh-3, Kh-4, and Kh-5). The average porosity in the Kh-1, Kh-3, and $\mathrm{Kh}-5$ is equal and $>10 \%$

- The calculated shale volumes using Larionov model for Tertiary rocks showed that the shale content in the Khurmala Formation is $>10 \%$ in the most interval. As result, this formation considered as shale rock in terms of reservoir characterization

- The formation is characterized as water-bearing reservoir based on the flow test result, mud logging result, and resistivity log deflection. However, the Khurmala Formation located in the fracture zone, but the clay contents blocked the pore connectivity and reduced the permeability. Consequently, the migrated hydrocarbon avoided to be accumulated in this interval.

\section{ACKNOWLEDGMENTS}

The research data were provided by Taq Taq Operation Company - TTOPCO and Genel Energy. We would like to thank the geology and administrations staffs from the operated companies in Taq Taq field.

\section{REFERENCES}

Adam, A., Swennen, R., Abdulghania, W., Abdlmutalib, A., Hariria, M. and Abdulraheem, A., 2018. Reservoir heterogeneity and quality of Khuff carbonates in outcrops of central Saudi Arabia. Marine and Petroleum Geology, 89, pp.721-751.

Al-Qayim, B. and Othman, D., 2012. Reservoir characterization of an intra- 
orogenic carbonates platform: Pila spi formation, taq taq oil field, Kurdistan, Iraq. Geological Society, 370, pp.139-168.

Al-Qayim, B. and Rashid, F., 2012. Reservoir characteristics of the albian upper qamchuqa formation carbonates, taq taq oilfield, Kurdistan, Iraq. Journal of Petroleum Geology, 35, pp.317-341.

Al-Qayim, B.A. and Othman, D.H., 2010. Lithofacies association, dolomitization, and potentiality of the pila spi formation, taq taq oil field, Kurdistan region, NE Iraq. Iraqi Bulletin of Geology and Mining, 6(2), pp.95-114.

Ameen, M.S., 1991. Possible forced folding in the taurus-zagros belt of Northern Iraq. Geological Magazine, 128(6), pp.561-584.

Aqrawi, A.A.M., Goff, J.C., Horbury, A.D. and Sadooni, F.N., 2010. The Petroleum Geology of Iraq. Scientific Press, Beaconsfield. p.424.

Asquith, G. and Krygowski, D., 2004. Basic Well Log Analysis. AAPG, Tulsa, Oklahoma. p.244.

Bhuyan, K. and Passey, Q.R., 1994. Clay Estimation from Gamma Ray and Neutron-density Porosity Logs. SPWLA, $35^{\text {th }}$ Annual Logging Symposium, Tulsa.

Dahlberg, K.E., 1989. A Practical Model for Analysis of Compensated Neutron Logs in Complex Formations. SPWLA Annual Logging Symposium, Denver.

Ellis, D.V. and Singer, J.M., 2007. Well Logging for Earth Scientists. Netherlands Springer, Dordrecht.

Garland, C.R., Abalioglu, I., Akca, L., Cassidy, A., Chiffoleau, Y., Godail, L., Grace, M.A.S., Kader, H.J., Khalek, F., Legarre, H., Nazhat, H.B. and Sallier, B., 2010. Appraisal and development of the Taq Taq field, Kurdistan region, Iraq. Geological Society, London, Petroleum Geology Conference Series, 7, pp.801-810.

Ghafur, A.A. and Hasan, D.A., 2017. Petrophysical properties of the upper qamchuqa carbonate reservoir through well log evaluation in the Khabbaz oilfield. Journal of Science and Engineering, 1(1), pp.72-88.

Hollis, C., 2011. Diagenetic on controls reservoir properties of carbonate successions within the Albian turonian of the Arabian plate. Petroleum Geoscience, 17, pp.223-241.

Hollis, C., Lawrence, D.A., Perière, M.D., Al Darmaki, F., 2017. Controls on porosity preservation within a Jurassic oolitic reservoir complex, UAE. Marine and Petroleum Geology, 88, pp.888-906.

Hussein, D., Collier, R., Lawrence, J., Rashid, F., Glover, P.W.J., Lorinczi, P. and Baban, D.H., 2017. Stratigraphic correlation and paleoenvironmental analysis of the hydrocarbon-bearing early miocene euphrates and jeribe formations in the Zagros folded thrust-belt. Arabian Journal of Geosciences, 10, pp.543-554.

Hussein, D., Lawrence, J., Rashid, F., Glover, P. and Lorinczi, P., 2018. Developing Pore Size Distribution Models in Heterogeneous Carbonates Using Especially Nuclear Magnetic Resonance. In: Engineering in Chalk: Proceedings of the Chalk 2018 Conference. ICE Publishing, London. pp.529-534.

Hussein, D.O., 2015. Reservoir Characterization of Ramp Carbonates: Lessons from the Lower Miocene Euphrates and Jeribe Formations, Kurdistan, N. Iraq Doctoral Dissertation, University of Leeds.

Jafarian, A., Fallah-Bagtash, R., Mattern, F. and Heubeck, C., 2017. Reservoir quality along a homoclinal carbonate ramp deposit: The permian upper Dalan formation, South pars field, Persian Gulf Basin. Marine and Petroleum Geology, 88, pp.587-604.

Jassim, S.Z. and Goff, J.C., 2006. The Geology of Iraq. Dolin, Prague. p.341.

Kamel, M.H. and Mabrouk, W.M., 2003. Estimation of shale volume using a combination of the three porosity logs. Journal of Petroleum Science and
Engineering, 20, pp.145-157.

Krygowski, D.A., 2003. Guide to Petrophysical Interpretation. Wyoming University, Austin Texas USA. p.147.

Mackertich, D.S. and Samarrai, A.I., 2015. History of hydrocarbon exploration in the Kurdistan region of Iraq. GeoArabia, 20(2), pp.181-220.

Normi, R. and Standen, E., 1997. Middle East Evaluation Well Review.

North Oil Company-Kirkuk (NOC), 1987. Final Well Report of Exploration Well Number 1 in Taq Taq Oil Field.

Rashid, F., Glover, P.W.J., Lorinczi, P., Collier, R. and Lawrence, J., 2015a. Porosity and permeability of tight carbonate reservoir rocks in the North of Iraq. Journal of Petroleum Science and Engineering, 133, pp.147-161.

Rashid, F., Glover, P.W.J., Lorinczi, P., Hussein, D. and Lawrence, J., 2017. Microstructural controls on reservoir quality in tight oil carbonate reservoir rocks. Journal of Petroleum Science and Engineering, 156, pp.814-826.

Rashid, F., Glover, P.W.J., Lorinczi, P., Hussein, D., Collier, C. and Lawrence. J., 2015b. Permeability prediction in tight carbonate rocks using capillary pressure measurements. Marine and Petroleum Geology, 68, pp.536-550.

Rashid, F., Hussein, D., Lawrence, J.A. and Khanaqa, P., 2020. Characterization and impact on reservoir quality of fractures in the cretaceous qamchuqa formation, Zagros folded belt. Marine and Petroleum Geology, 113, pp.104-117.

Rashid, F.N., 2015. The Kometan Formation: Reservoir Characteristics of Tight Carbonates in the Western Zagros Basin. Doctoral Dissertation, University of Leeds.

Rider, M.H. and Kenedy, M., 2011. The Geological Interpretation of Well Logs. Rider-French Consulting Ltd., Sutherland. p.280.

Ryder Scott Company, 2011. Estimated Unrisked Discovered and Undiscovered Total Petroleum Initially in Place Attributable to Certaininterests in the Shaikan License Block, Kurdistan, Iraq. Report Prepared for Gulf Keystone Petroleum Ltd., Iraq.

Schlumberger, 1997. Log Interpretation/Charts. Schlumberger Wireline and Testing, Houston, USA.

Schlumberger, 2012. Definition of porosity: How porosity is measured. Oil Field Review Autumn, 24(3), pp.63-64.

Sherwani, G.H. and Zangana, H.A. 2017. Reservoir characterization of early jurassic formations in selected wells in the duhok governorate, Iraqi Kurdistan region. Journal of Science and Engineering, 1(1), pp.11-18.

Sissakian, V.K., Ibrahim, E.I., Ibrahim, F.A., and Al-Ali, N.M. 2000. Geological map of Iraq, Scale 1: 1000000, Sheet No. 1. $3^{\text {rd }}$ ed. State Company of Geological Survey and Mining, Baghdad, Iraq.

Taq Taq Operation Company, 2006. Final Well Report of Development Well Number 5 in Taq Taq Oil Field.

Taq Taq Operation Company, 2007. Final Well Report of Development Well Number 7 in Taq Taq Oil Field.

Van Bellen, R.C., Dunnington, H.V., Wetzel, R. and Morton, D.M., 1959. Lexique Stratigraphique International: 0310 Asie (Iraq). Paris: Centre National de la Recherche Scientifique Reprinted by Gulfpetro Link, 2005.

Wiley, R. and Pachett, J.G., 1990. CNL (Compensated Neutron Log) Neutron Porosity Modeling, a Step Forward. SPWLA $30^{\text {th }}$ Annual Logging Symposium.

Zebari, M.M. and Burberry, C.M., 2015. 4-D evolution of anticlines and implications for hydrocarbon exploration within the Zagros fold-thrust belt, Kurdistan region, Iraq. GeoArabia, 20, pp.161-188. 